\title{
Estimation and correlation of chlorophyll and nitrogen contents in Psidium guajava L. with destructive and non-destructive methods
}

\section{Estimación y correlación de contenidos de clorofilas y nitrógeno en Psidium guajava L. mediante métodos destructivos y no destructivos}
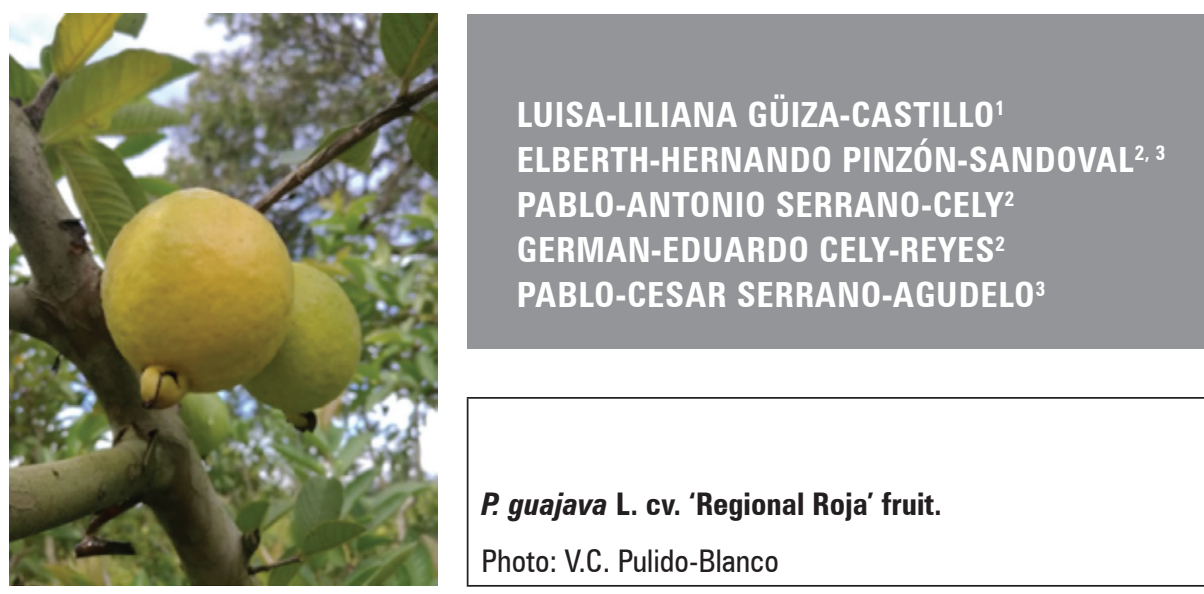

\begin{abstract}
Estimating photosynthetic pigments, such as chlorophylls, as well as the foliar nitrogen content is very important for the evaluation of the nutritional and physiological status of a plant. However, producers cannot easily carry out these estimations because they involve analyses in laboratories that are costly and time-consuming. The SPAD-502 total chlorophyll index meter is efficient at rapidly estimating total chlorophyll contents in situ, along with its relationship with the total nitrogen concentration in tissues. The objective of this research was to validate a non-destructive in situ method (SPAD) for use in place of destructive estimation methods for chlorophylls a, b and total, as well as the foliar nitrogen concentration in guava plants (Psidium guajaba L.), cv. Regional Roja, in three phenological stages under the conditions of the municipality of Vélez-Santander (Colombia). The data obtained with the SPAD-502 and the content of chlorophylls a, b and total were adjusted to a second-degree polynomial with correlation coefficients $(r)$ greater than 0.91 for the three phenological stages, while the concentration of foliar nitrogen was adjusted to a linear type model with determination coefficients $\left(R^{2}\right)$ higher than 0.90 , indicating a highly linear correlation between the non-destructive method and the destructive methods used in the present study.
\end{abstract}

Additional key words: SPAD; photosynthetic pigments; mineral nutrition; portable meter; nutritional status.

Servicio Nacional de Enseñanza (SENA), Vélez (Colombia). ORCID Güiza-Castillo, L.-L.: 0000-0002-5677-5038

2 Universidad Pedagógica y Tecnológica de Colombia, Grupo de Investigación GIPSO, Tunja (Colombia). ORCID

Pinzón-Sandoval, E.-H.: 0000-0001-9229-3450; ORCID Serrano-Cely, P.-A.: 0000-0002-1270-3024; ORCID Cely-Reyes, G.-E.: 0000-0001-6312-3575; ORCID Serrano-Agudelo, P.-C.: 0000-0002-2563-2050

3 Corresponding author. elberth.pinzon@uptc.edu.co 


\section{RESUMEN}

La estimación de pigmentos fotosintéticos como las clorofilas, así como el contenido de nitrógeno foliar son muy importantes para la evaluación del estatus nutricional y fisiológico de la planta; sin embargo, los productores no pueden acceder de forma fácil a estos, debido a que implican el análisis en laboratorios que en ocasiones generan costo y demora en la obtención de los resultados. El medidor de índice de clorofila total tipo SPAD-502 es un equipo que ha demostrado su eficiencia en cuanto a la estimación rápida de los contenidos totales de clorofila in situ, así también, su relación con la concentración del nitrógeno total en tejido. El objetivo de la investigación fue el de validar el método in situ, no destructivo (SPAD) frente a los métodos de estimación destructivos de clorofilas a, b y total, así como la concentración de nitrógeno en tejido foliar en plantas de guayaba (Psidium guajaba L.) cv. Regional Roja en tres estadios fenológicos, bajo condiciones del municipio de Velez-Santander (Colombia). Los datos obtenidos con el SPAD-502 y el contenido de clorofilas a, b y total, se ajustaron a un polinomio de segundo grado con coeficientes de correlaciones (r) mayores a 0,91, en los tres estadios fenológicos evaluados, mientras que la concentración de nitrógeno foliar se ajustó a un modelo de tipo lineal con coeficientes de determinación $\left(R^{2}\right)$ superior al 0,90 , esto indica la existencia de una alta correlación lineal entre el método no destructivo y los métodos destructivos empleados en el presente estudio.

Palabras clave adicionales: SPAD; pigmentos fotosintéticos; nutrición mineral; medidor portátil; estatus nutricional.

Received for publication: 01-02-2020 Accepted for publication: 30-03-2020

INTRODUCTION

The mineral nutrition of crops is of great concern for producers, who currently use diagnostic tools, such as soil and/or tissue analysis that are costly, timeconsuming and inhibit quick decision-making. For tissue or photosynthetic pigment analyses, destructive methodologies are used that, although important in the evaluation of the physiological status of plants, are expensive and inaccessible for producers (Amarante et al., 2009). Furthermore, because of the importance of nitrogen as a primary element in tissue formation (Marschner, 2012), methodologies used for its quantification in laboratories are very costly and require the transport of samples and a lot of time, delaying the implementation of corrective measures for deficiencies of this element.

The early detection of the chlorophyll or nitrogen content in plants facilitates decision-making for dealing with element deficiencies, such as nitrogen $(\mathrm{N})$ and magnesium, which is why diagnosis in a timely manner is essential for producers. Traditionally, farmers use visual parameters such as the greenness of the leaves to determine the need for N. However, this indicator is highly subjective, which is why methods that guarantee a rapid and quantitative diagnosis are needed.
The measurement of variables, such as the chlorophyll index, with non-destructive methods is a widely used technique for different species (Castañeda et al., 2018; Mendoza-Tafolla et al., 2019), including the commonly used SPAD total chlorophyll index type meter. This portable device indirectly, with a nondestructive method, evaluates the total chlorophyll index in leaves by means of light transmitted through the leaf, with the wavelengths 650 and $940 \mathrm{~nm}$, providing an excellent approximation of the total chlorophyll content and $\mathrm{N}$ nutritional status in various crops (Zotarelli et al., 2003).

Several studies have indicated the existence of a direct relationship between the chlorophyll content and the $\mathrm{N}$ content in leaves because this element is needed for the synthesis of the chlorophyll molecule and is linked to the light phase of the photosynthetic process (Taiz and Zeiger, 2010). Studies carried out by Zotarelli et al. (2003) indicated the importance of using indirect methods, such as the SPAD-502 ${ }^{\circledR}$ chlorophyll meter (Konica Minolta, Osaka, Japan), for monitoring the availability of N. Ramírez-Builes et al. (2012) proposed the use of portable chlorophyll meters as a tool for the early detection of $\mathrm{N}$ deficiencies and yield decreases associated with stress conditions. 
The SPAD-502 ${ }^{\circledR}$ chlorophyll meter has been used successfully in the quantification of nitrogen content in crops such as vine apples (Callejas et al., 2014; Castañeda et al., 2018), corn (Castillo and Ligarreto, 2016), basil (Fenech-Larios et al., 2009), and tomatoes (Rodríguez et al., 1998; Hurtado et al., 2017), among others, because this method is easy, fast, and non-destructive.

Therefore, the present study aimed to estimate the concentrations of chlorophyll and nitrogen in guava leaves (Psidium guajava L.) in different phenological stages in order to observe their correlation with the non-destructive SPAD method under field conditions.

\section{MATERIALS AND METHODS}

This study was carried out on the San Diego farm, village of Aco de Peña Blanca, which is located in the municipality of Vélez-Santander, with longitude and latitude coordinates: $73^{\circ} 39^{\prime} 30^{\prime \prime} \mathrm{W}$ and $5^{\circ}{ }^{\circ} 7^{\prime} 49^{\prime \prime}$ $\mathrm{N} ; 1,920 \mathrm{~m}$ a.s.1. The study area was $1 \mathrm{ha}$, which was georeferenced to fully identify the area in terms of its geographical characteristics and the trees it contained. Four hundred eight trees in the P. guajava cv. Regional Roja were identified, which were 5 years old, in the productive stage, established with a planting distance of $5 \mathrm{~m}$ between plants and $5 \mathrm{~m}$ between rows and traditionally managed, of the 408 trees, 44 trees were selected that belonged to the area, where, historically, this crop has shown good growth and development.

For the quantification of the SPAD total chlorophyll index, the $\mathrm{a}, \mathrm{b}$ and total chlorophyll contents and the nitrogen content in the tissue, three sampling times were established in the 44 selected plants in order to measure these variables at points where the plants see greater absorption of elements such as nitrogen: E2: visible flower buds, H1: fruit set and I1: fruit filling ( $80 \%$ of total formation), selected according to the phenological scale proposed by Salazar et al. (2006) and carried out with general pruning of the evaluated plants.

To determine the total chlorophyll index in the field, 20 leaves were selected from the branches located in the middle third of the plants, which were fully expanded, in order to quantify the index using a SPAD$502{ }^{\circledR}$ (Konica Minolta, Osaka, Japan), obtaining the average value per sample unit.
The $\mathrm{a}, \mathrm{b}$ and total chlorophyll contents were estimated in a laboratory with a spectrophotometer, Thermo Scientific ${ }^{\mathrm{TM}}$ Genesys ${ }^{\mathrm{TM}} 10$ series, following the methodology proposed by Solarte et al. (2010). For this, 0.5 $\mathrm{cm}$ radius leaf discs were taken from the middle part of the leaves (between the central rib and the margin) until reaching $5 \mathrm{~g}$ (6 leaves), which were placed in a mortar with $14 \mathrm{~mL}$ of $80 \%(\mathrm{v} / \mathrm{v})$ acetone previously cooled to $-10^{\circ} \mathrm{C}$, macerated for $5 \mathrm{~min}$, vortexed for 2 min in order to ensure complete contact of the plant material with the acetone, and centrifuged for $10 \mathrm{~min}$ at $4000 \mathrm{rpm}$. The supernatant was removed, placed in a $25 \mathrm{~mL}$ volumetric balloon, which was covered with aluminum foil, and titrated with previously cooled $80 \%(\mathrm{v} / \mathrm{v})$ acetone. The entire process was carried out with low illumination. Finally, an absorbance reading was taken for each sample at a $663 \mathrm{~nm}$ wavelength for chlorophyll a and $647 \mathrm{~nm}$ for chlorophyll $\mathrm{b}$. The analytical blank was $80 \%$ acetone $(\mathrm{v} / \mathrm{v})$. The chlorophyll $a, b$ and total contents were calculated with the data using the equations proposed by Lichtenthaler (1987) for 80\% acetone (v/v) (Equations 1, 2 and 3):

$$
\begin{gathered}
\text { Chl } \mathrm{a}=12.25 \mathrm{~A}_{663.2}-2.79 \mathrm{~A}_{646.8} \\
\mathrm{Chl} \mathrm{b}=21.50 \mathrm{~A}_{646.8}-5.10 \mathrm{~A}_{663.2} \\
\text { Chl total }(\mathrm{a}+\mathrm{b})=7.15 \mathrm{~A}_{663.2}-18.71 \mathrm{~A}_{646.8}
\end{gathered}
$$

The tissue nitrogen content was determined with the Kjeldahl method using 150 g samples (15 leaves) of plant material, quantifying the SPAD chlorophyll index. The samples were covered with absorbent paper to eliminate moisture and packed in labeled paper bags, which were stored in a polystyrene refrigerator. The analyses were carried out in the ASAYMA laboratory, Palmira-Colombia.

The data obtained for the chlorophyll a, b and total contents ( $\mathrm{mg} \mathrm{g}^{-1}$ fresh weight) and the nitrogen content in the leaf tissue (\%) were correlated with the data obtained from the total chlorophyll index (SPAD) in order to obtain the respective graphs and regression equations. The correlation analyses were done with the statistical software R 3.6.2, free version.

\section{RESULTS AND DISCUSSION}

The data analysis showed the linear relationship between the total chlorophyll index (SPAD) and the chlorophyll $\mathrm{a}, \mathrm{b}$ and total contents obtained with 
spectrophotometry for the three evaluated stages (E2, H1, I1). According to the results of the Pearson method correlation analysis, a linear association was observed between the SPAD method and the chlorophyll $a, b$ and total tissue contents, with positive and significant correlation coefficients for all stages with values that ranged from 0.91 to 0.97 (Fig. 1).

The total chlorophyll index was between 29.0 and 51.9 SPAD units for the evaluated stages, while the total chlorophyll (Chla + Chlb) for stage E2 presented a minimum value of 0.91 and a maximum of 3.45 (Fig. 2); stage $\mathrm{H} 1$ presented a minimum value of 0.56 and a maximum of 2.76 (Fig. 3) and stage I1 presented a minimum value of 0.97 and a maximum of 2.86 (Fig. 4).

The above indicated that the quantification of the chlorophyll content, either directly or indirectly, was influenced by the phenological stage. The SPAD method was an important tool for determining the tissue chlorophyll contents, quickly and reliably, in the guava plants under the study conditions and in the evaluated stages.

The results indicated that the SPAD method was highly correlated with the content of photosynthetic pigments, such as chlorophyll a, b and total. According to the polynomial model, an $R^{2}$ value greater than or equal to $0.90(n=44 ; P \leq 0.0001)$ was obtained in all evaluated stages, indicating that there was a highly significant and positive correlation between the destructive method and the SPAD method (Fig. 2, 3, 4).

These results agree with those of studies on various species (Zotarelli et al., 2003; Torres Netto et al., 2005; Hurtado et al., 2017). The selection of leaves from the middle third was successful since there was no evidence of high variation in terms of data; similar results were described by Castillo and Ligarreto (2016), who, when evaluating the SPAD method in corn plants, concluded that the best area for sampling is the middle third of the plant.

The results agree with the report by Torres Netto et al. (2005), who indicated that, in coffee leaves, polynomial equations generate the best correlation between the SPAD method and the destructive method. Donnelly et al. (2020) observed that the quadratic model showed the best fit when correlating the SPAD method and the chlorophyll contents extracted from leaves of different tree species. However, the results differed when compared to the behavior of other species with respect to the mathematical adjustment of the studied relationships, such as in tomatoes and cotton, in which the relationships between SPAD readings and the concentrations of photosynthetic pigments were linear (Rodríguez et al., 1998; Neves et al., 2005; Jiang et al., 2017).

The results agree with the report by Torres Netto et al. (2005), who indicated that, in coffee leaves, polynomial equations generate the best correlation between the SPAD method and the destructive method. Donnelly et al. (2020) observed that the quadratic model showed the best fit when correlating the SPAD method and the chlorophyll contents extracted from leaves of different tree species. However, the results differed when compared to the behavior of other species with respect to the mathematical adjustment of the studied relationships, such as in tomatoes and cotton, in which the relationships between SPAD readings and the concentrations of photosynthetic pigments were linear (Rodríguez et al., 1998; Neves et al., 2005; Jiang et al., 2017).

Notably, method validation should be carried out for each crop as far as possible under real production conditions (field or greenhouse) because different variations can be generated, including variations in the morphological type, such as an increase or decrease in the leaf thickness, in the physiological type, such as a greater or lesser content of photosynthetic pigments, in the environmental type, such as greater or lesser exposure to light, and in the different genotypes of a species (Jifon et al., 2005; Uddling et al., 2007).

The results for the correlation between the percentage of nitrogen and the SPAD units were similar to those found for the chlorophyll a, b and total contents although it differed in terms of the mathematical model since, in this case, it was adjusted to linear equations. The chlorophyll index values ranged between 34.0 and 51.7 for the SPAD units and 0.7 and $2.46 \%$ for the nitrogen content in the leaf tissue (Fig. $5 \mathrm{~A}, \mathrm{~B}$ and $\mathrm{C})$.

According to the linear model, coefficient of determination values $\left(R^{2}\right)$ greater than or equal to 0.90 $(n=44 ; P \leq 0.0001)$ were obtained in all evaluated stages (Fig. 5), indicating the existence of a high correlation between the foliar nitrogen content and total chlorophyll index (SPAD). The results agree with the observations of Mendoza-Tafolla et al. (2019), who indicates that readings with a SPAD type meter 
presented a high correlation $(P=0.01)$ with the foliar nitrogen concentration in L. sativa plants. Which were adjusted to a simple linear regression, with a positive correlation coefficient of 0.95 and a coefficient of determination $\left(R^{2}\right)$ of 0.90 . On the other hand, Yue et al. (2020), when performing a correlation analysis of the SPAD method and the nitrogen concentration in wheat plants, indicated adjustment to a second-degree polynomial in different phenological stages and at different times of evaluation.

The nitrogen content in the soil or nutrient solution influenced the SPAD readings and their correlation with the percentage of nitrogen in the leaves. In the present study, the correlation between the methods was positive, connected to the amount of data used and the selection of suitable leaves for the measurement (Figure 5A, B and C). The significance of the correlation depended on the position of the leaf, indicating that, in the middle third, there was high $\mathrm{N}$ mobility in the plants since it moves more easily to organs with high transpiration and active photosynthetic processes, as compared to leaves in the upper third, in which said processes are incipient, or leaves in the lower third, in which said processes can be affected by senescence processes (Malavolta et al., 1997). Since the purpose of the SPAD method is to quickly diagnose element deficiencies without visual symptoms, the evaluation of middle-third leaves is more accurate over time (Azia and Stewart, 2001).

\section{CONCLUSION}

In the present study, there was a significant correlation between the measurement of the total chlorophyll index (SPAD) and the concentration of chlorophyll a, b and total extractable and the percentage of nitrogen in the foliar tissue, quantified in leaves from the middle third of the guava plants in three phenological stages of the reproductive phase, cultivated under the conditions of the municipality of Vélez-Santander. Linear regression equations were obtained for the nitrogen content in the leaf tissue, and second-degree polynomials were obtained for the chlorophyll $a, b$ and total extractable from the SPAD units.

This study confirmed the usefulness and convenience of using the SPAD technique for the non-destructive determination of chlorophyll and nitrogen contents in foliar tissue in guava plants under field conditions since it is an easy, fast and efficient method; however, the sample used must be representative and sufficient for generating a good correlation.

\section{ACKNOWLEDGMENTS}

The authors thank the Centro de Gestion Agroempresarial del Oriente SENA-Vélez, Línea de investigación SENNOVA for financing this project.

Conflict of interests: The manuscript was prepared and reviewed with the participation of the authors, who declare that there exists no conflict of interest that puts at risk the validity of the presented results.

\section{BIBLIOGRAPHIC REFERENCES}

Amarante, C.V.T., O.Z. Zanardi, A. Miqueloto, C.A. Steffens, J. Erhart, and J.A.D. Almeida. 2009. Quantificação da área e do teor de clorofilas em folhas de plantas jovens de videira "Cabernet sauvignon" mediante métodos não destrutivos. Rev. Bras. Frutic. 31(3), 680-686. Doi: 10.1590/S0100-29452009000300009

Azia, F. and K.A. Stewart. 2001. Relationships between extractable chlorophyll and SPAD values in muskmelon leaves. J. Plant Nutr. 24(6), 961-966. Doi: 10.1081/ PLN-100103784

Callejas, R., E. Kania, A. Contreras, C. Peppi, and L. Morales. 2014. Evaluación de un método no destructivo para estimar las concentraciones de clorofila en hojas de variedades de uva de mesa. Idesia (Arica), 31(4), 1926. Doi: $10.4067 /$ s0718-34292013000400003

Castañeda, C.S., P.J. Almanza-Merchán, E.H. Pinzón-Sandoval, G.E. Cely-Reyes, and P.A. Serrano-Cely. 2018. Estimación de la concentración de clorofila mediante métodos no destructivos en vid (Vitis vinifera L.) cv. Riesling Becker. Rev. Colomb. Cienc. Hortic. 12(2), 329-337. Doi: 10.17584/rcch.2018v12i2.7566

Castillo, Á.R. and G.A. Ligarreto. 2016. Relación entre nitrógeno foliar y el contenido de clorofila, en maíz asociado con pastos en el Piedemonte Llanero colombiano. Corpoica Cienc. Tecnol. Agropecu. 11(2), 122. Doi: 10.21930/rcta.vol11_num2_art:202

Donnelly, A., R. Rehberg C. Yu, G. Meyer, and E.B. Young. 2020. Leaf chlorophyll estimates of temperate deciduous shrubs during autumn senescence using a SPAD502 meter and calibration with extracted chlorophyll. Ann. For. Sci. 77(2). Doi: 10.1007/s13595-020-00940-6

Fenech-Larios, L., E. Troyo-Diéguez, M. Trasviña-Castro, F. Ruiz-Espinoza, A. Beltrán-Morales, B. Murillo-Amador, J. García-Hernández, and S. Zamora-Salgado. 2009. Relación entre un método no destructivo y uno de extracción destructivo, para medir el contenido de 
clorofila en hojas de plántula de albahaca (Ocimum basilicum L). Univer. Cienc. 25(1), 99-102.

Hurtado, E., F. Gonzalez-Vallejos, C. Röper, E. Bastías, and P. Mazuela. 2017. Propuesta para la determinación del contenido de clorofila en hojas de tomate. Idesia 35(4), 129-130. Doi: 10.4067/S0718-34292017000400129

Jiang, C., M. Johkan, M. Hohjo, S. Tsukagoshi, and T. Maturo. 2017. A correlation analysis on chlorophyll content and SPAD value in tomato leaves. HortResearch (71), 37-42. Doi: 10.20776/S18808824-71-P37

Jifon, J.L., J.P. Syvertsen, and E. Whaley. 2005. Growth environment and leaf anatomy affect nondestructive estimates of chlorophyll and nitrogen in Citrus sp. leaves. J. Am. Soc. Hort. Sci. 130(2), 152-158. Doi: 10.21273/ jashs.130.2.152

Lichtenthaler, H.K. 1987. Chlorophylls and carotenoids: pigments of photosynthetic biomembranes. Methods Enzymol. 148(C), 350-382. Doi: 10.1016/0076-6879(87)48036-1

Malavolta, E., G.C. Vitti, and S.A. Oliveira. 1997. Avaliação do estado nutricional das. $2^{\text {nd }}$ ed. Potafos, Piracicaba, Brazil.

Marschner, P. 2012. Mineral nutrition of higher plants. $3^{\text {th }}$ ed. Elsevier, New York, NY.

Mendoza-Tafolla, R.O., P. Juarez-Lopez, R.E. Ontiveros-Capurata, M. Sandoval-Villa, I. Alia-Tejacal, and G. Alejo-Santiago. 2019. Estimating nitrogen and chlorophyll status of romaine lettuce using SPAD and at LEAF readings. Not. Bot. Horti. Agrobo. 47(3), 751756. Doi: $10.15835 /$ nbha47311525

Neves Caires, O.S., J.G.D. Carvalho, F.A.D. Martins, T.R.P.D. Pádua, and P.J.D. Pinho. 2005. Uso do SPAD502 na avaliação dos teores foliares de clorofila, nitrogênio, enxofre, ferro e manganês do algodoeiro herbáceo. Pesq. Agropec. Bras. 40(5), 517-521. Doi: 10.1590/S0100-204X2005000500014

Ramírez Builes, V.H., M. Moreno Berrocal, and J.C. López Ruiz. 2012. Evaluación temprana de la deficiencia del nitrógeno en café y aplicaciones. Avan. Téc. Cenicafé (11), 1-7.

Rodríguez, M., G. Alcántar, A. Aguilar, J. Etchevers, and J. Santizó. 1998. Estimation of nitrogen and chlorophyll status of tomato with a portable chlorophyll meter. Terra 16(2), 135-141.

Salazar, D.M., P. Melgarejo, R. Martínez, J.J. Martínez, F. Hernández, and M. Burguera. 2006. Phenological stages of the guava tree (Psidium guajava L.). Sci. Hortic. 108(2), 157-161. Doi: 10.1016/j.scienta.2006.01.022

Solarte, M., L. Moreno, and L. Melgarejo. 2010. Fotosíntesis y pigmentos vegetales. pp. 107-122. In: Melgarejo, L. (ed.). Experimentos en fisiología y bioquímica vegetal. Departamento de Biología, Universidad Nacional de Colombia, Bogota.

Taiz, L. and E. Zeiger. 2010. Plant physiology. $3^{\text {rd }}$ ed. Sinauer Associates, Sunderland, MA.

Torres Netto, A., E. Campostrini, J.G.D. Oliveira, and R.E. Bressan-Smith. 2005. Photosynthetic pigments, nitrogen, chlorophyll a fluorescence and SPAD-502 readings in coffee leaves. Sci. Hortic. 104(2), 199-209. Doi: 10.1016/j.scienta.2004.08.013

Uddling, J., J. Gelang-Alfredsson, K. Piikki, and H. Pleijel. 2007. Evaluating the relationship between leaf chlorophyll concentration and SPAD-502 chlorophyll meter readings. Photosynth. Res. 91(1), 37-46. Doi: 10.1007/ s11120-006-9077-5

Yue, X., Y. Hu, H. Zhang, and U. Schmidhalter. 2020. Evaluation of both SPAD reading and SPAD index on estimating the plant nitrogen status of winter wheat. Int. J. Plant Prod. 14(1), 67-75. Doi: 10.1007/ s42106-019-00068-2

Zotarelli, L., E.G. Cardoso, J.L. Piccinin, S. Urquiaga, R.M. Boddey, E. Torres, and B.J.R. Alves. 2003. Calibração do medidor de clorofila Minolta SPAD-502 para avaliação do conteúdo de nitrogênio do milho. Pesq. Agropec. Bras. 38(9), 1117-1122. Doi: 10.1590/ S0100-204X2003000900014 